\title{
Implementation of User Centered Design Method on e-Catalog Information System of UMKM in South Aceh Agency
}

\author{
Fardiansyah ${ }^{\mathrm{a},{ }^{*}}$, Anhar Pulungan ${ }^{\mathrm{b}}$, Ridha Sitorus ${ }^{\mathrm{a}}$, Muharratul Mina R ${ }^{\mathrm{a}}$ \\ ${ }^{a}$ Politeknik Aceh Selatan, Merdeka Street, Komplek Reklamasi Pantai, Tapaktuan city, 23751, Indonesia \\ ${ }^{b}$ Politeknik Negeri Medan, Jalan Almamater No. 1, Kampus USU Padang Bulan, Medan, 20155, Indonesia \\ *fardian.poltas@gmail.com
}

ARTICLE INFO

Article history:

Accepted

Keywords:

Sistem Informasi

e-Katalog

UMKM

Olshop

\section{ABSTRACT}

The utilization of digital technology produces efficiency, effectiveness and accountability that can support the UMKM (Usaha Mikro, Kecil, Menengah) so that the Regional Government (PEMDA) in this case the Koperasi and UKM Office of South Aceh agency can contribute in providing services and education for UMKM which are expected to be able to improve productivity and profit of UMKM in their region. To using of the UCD (User Centered Design) model involves the user in the development process. This study focuses on the implementation of the use of the UCD development model after going through the evaluation process of the user context, analysis and design of solutions based on recommendations from users. Based on the evaluation results, it is known that the implementation of UCD method to the system have a good response from users.

Copyright (C) 2021 Politeknik Aceh Selatan. All rights reserved.

\section{Introduction}

Information technology plays an important role in business world today that can be seen from various production process, distribution up to product marketing. This is triggered by the development of digital technology which causes a shift in the industrial market using the internet network. Olshop (Online Shop) is one example of UMKM business which is currently get experience to increase both in terms of type of business as well as business transaction records. Based on statistical results [1] it is stated that of 15.08 percent of businesses that have sell goods/services via the internet in all provinces in Indonesia with the categories of types of goods sold online in the form of food, beverages, groceries, clothing, footwear, mukena, accessories, services, beauty equipment and sales of cars and motorcycles.

To using User Centered Design (UCD) Method in the design aims to place the user at the center of a system development process, so that users can provide suggestions starting from the interface up to the final result of the system design stage which is expected to providing an overview of the solutions that suit for user needed.

The main topic in this study is to implement UCD Method on the e-Catalog Information System of UMKM in South Aceh Agency that which currently use manual method on processing UMKM data, so that it is less effective in supporting UMKM business actors in order to obtain services and educations that can increase UMKM productivity and profits in their working areas.

\section{A. Information Systems}

In general, an information system can be defined as a collection of interrelated information that is used to obtain certain information. The system is a collection of elements, components or variables that are organized, interacting, integrated and interdependent with one another [2]. Information is classified data in the decision-making process that aims to increase knowledge and reduce the uncertainty of information users. 
According to [3], information systems is data collected, grouped and processed in such a way as to be a unity of information that is interrelated and mutually supportive so that it becomes a valuable information for those who receive it. Furthermore, according to [4], information systems are systems that have the ability to collect information from all sources and use various media to display information.

\section{B. e-Katalog}

e-catalog is an electronic information system that lists, types, technical specifications and prices of certain Goods / Services from various Government Providers / Services. While according to the simple language e-catalog is a collection of information created in electronic form and able to provide accessibility to users online based on the internet [5].

\section{User Centered Design (UCD)}

UCD is a method used in interactive system development to develop a software or system. This method focuses on usability, needs, environment, tasks and workflows on its design, so that the target of system or software development is the user. The testing process involving the user from start to finish is done interactively and repeatedly.

\section{Method}

\section{A. System Issue}

In minimizing errors in the system to be made, researchers can use the User Centered Design (UCD) methodology approach as a method in collecting initial data, to find out the level of user usability to the system that has been running on each UKM and can also be used to know and analyze the needs of users (Users). The steps in doing this UCD method are as follows:

1. Spesify Context Of Use, identifying the people who will use the application both the purpose and what conditions they will use the application.

2. Spesify Requirement, identifying user needs (UMKM) and organization needs (Dinas Koperasi dan UMKM Kab. Aceh Selatan)

3. Create Design of Solution, create solutions to customized application needs

4. Evaluate Design, evaluate the design performed at the previous stage

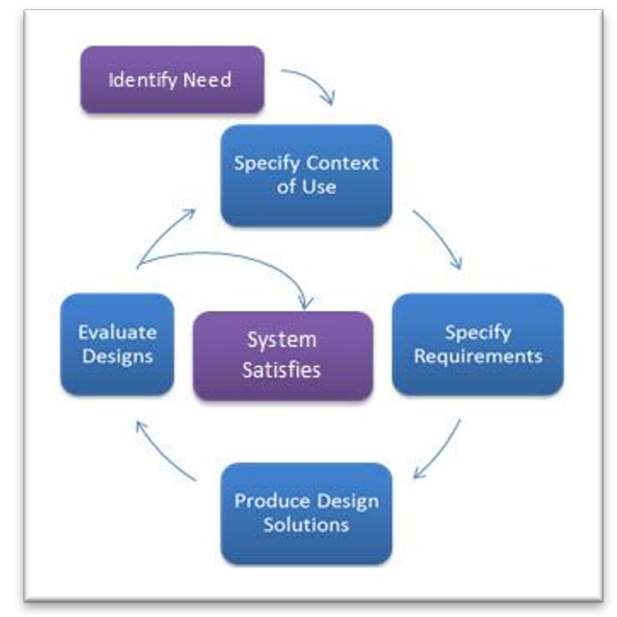

Figure 1. User Centered Design Process Method (ISO-9241-210:2019)

\section{B. Model Mapping}

Approach of UCD method, in the process conducted interview, FGD (Focus Group Discussion), Questionnaire, Observation directly to the place of UKM and get the system that is running on each UMKM which will be used as a prototype of the system to be built. 


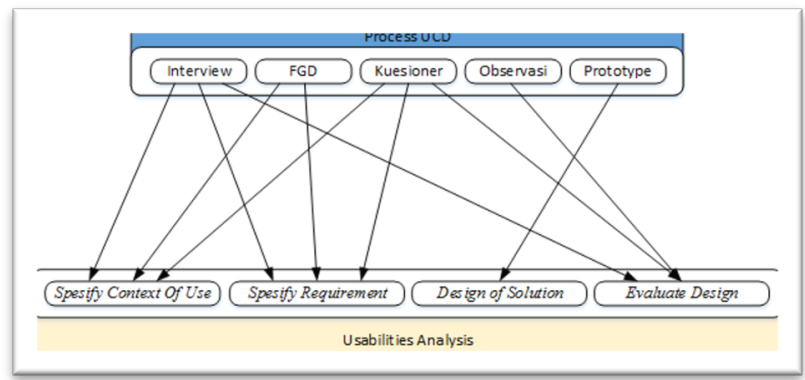

Figure 2. Mapping process approach UCD Method

\section{System Model Design}

This stage is carried out the process of making a more concrete solution design of the information system built. Here is the design produced as a solution of the system built.

\section{Context Diagram Design}

In describing the process of documentation data, input and output from the system, a representation of it is needed that is reflected into a context diagram as in figure 3 below.

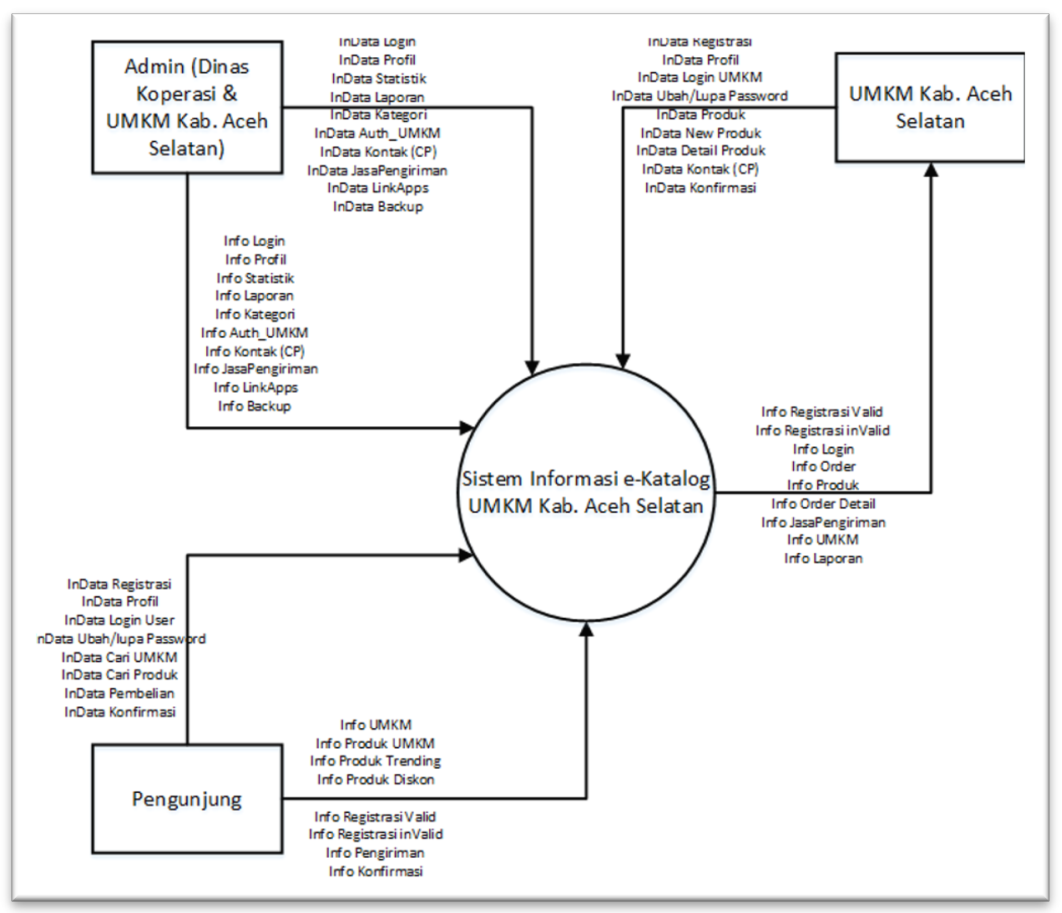

Figure 3. Context Diagram

2. Use Case Diagram design

To facilitate the design process in describing interactions between one or more actors, so it is need to design a Use Case diagram as in figure 4 below. 


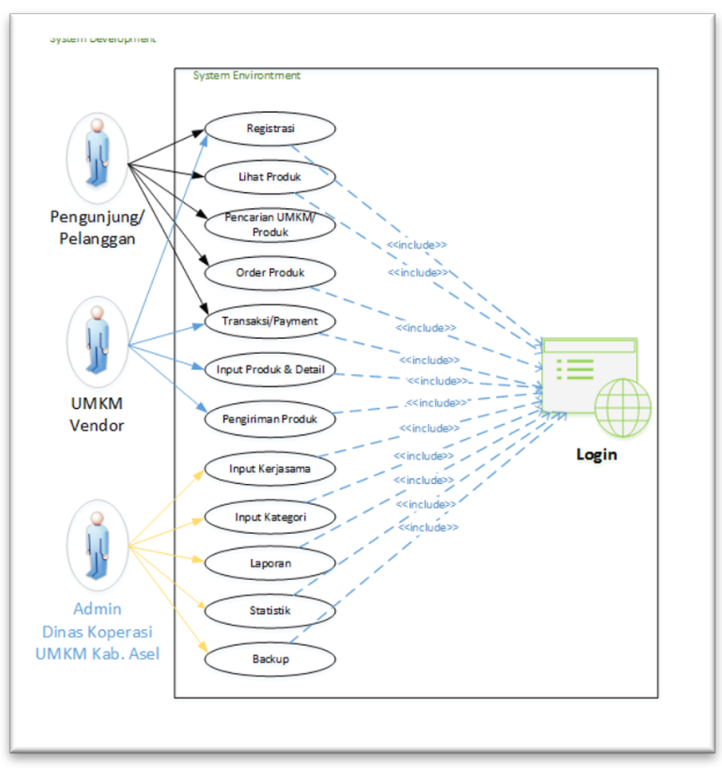

Figure 4. Use Case Diagram Design

\section{Activity Diagram Design}

To show the activities of each actor, so need an activity diagram such as activity diagram of booking and payment is needed below :

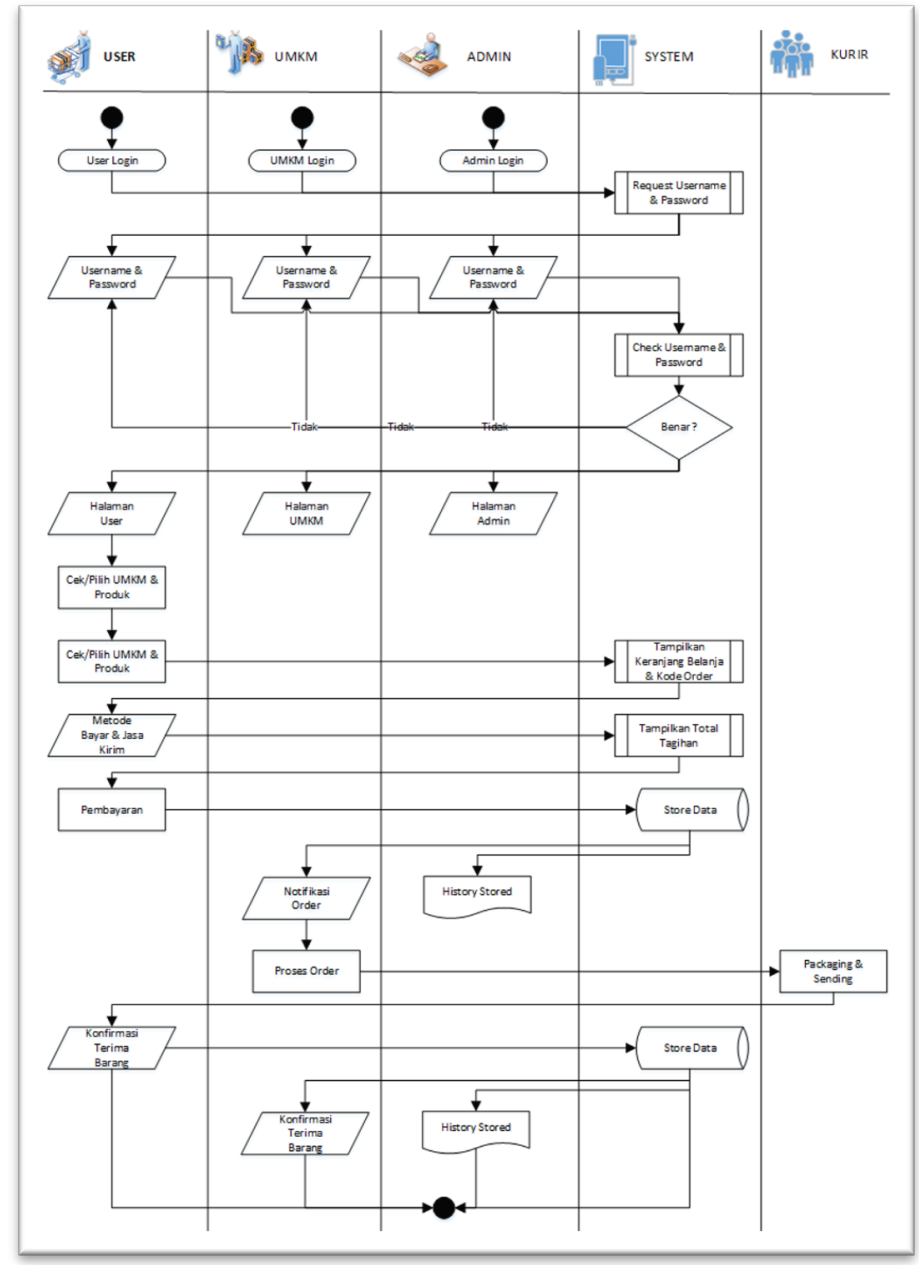

Figure 4. Activity Diagram Order \& payment Design 
4. Entity Relational Diagram Design (ERD)

The ERD design serves to show the entity relationships between data structures within the scope of the system created as seen in Figure 5 below .

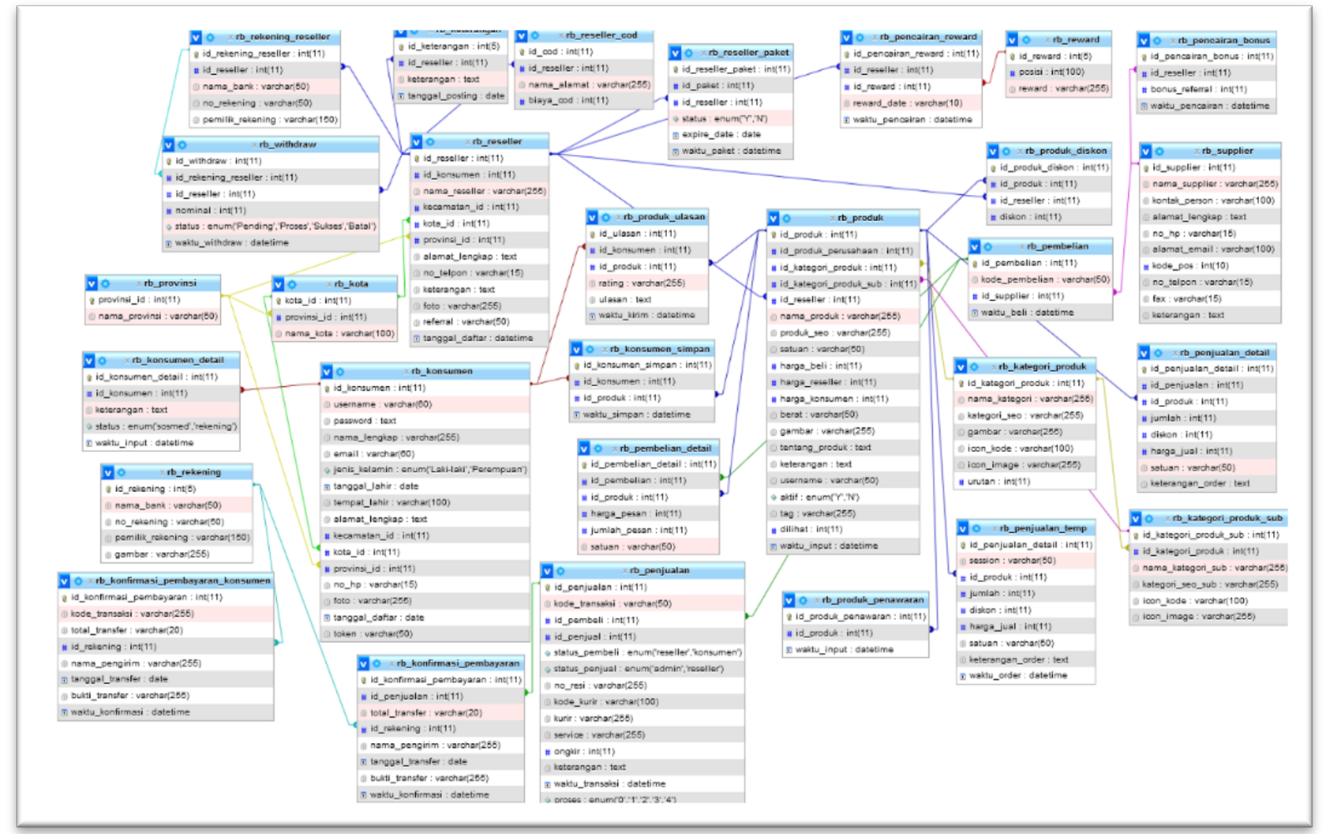

Figure 4. Entity Diagram

\section{Evaluate Model}

The process of evaluating the system using the USE Questionnaire method [7]. This method is used to measure aspects of user experience related to user behavior towards both software using and decision making to make purchases of a product. For the assessment scale will follow five (5) assessment weights as in table 3.1 below:

Tabel 1. Pilihan dan bobot penilaian likert [8] pada USE Questionnaire

\begin{tabular}{|c|c|c|c|c|c|}
\hline Pilihan & $\mathbf{1}$ & $\mathbf{2}$ & $\mathbf{3}$ & $\mathbf{4}$ & $\mathbf{5}$ \\
\hline Nilai & 1 & 0,75 & 0,5 & 0,25 & 0 \\
\hline
\end{tabular}

Variable measurement uses the Likert scale which measures a person's attitudes, opinions and perceptions by giving a score to each alternative answer. The instrument used in the form of a list of questions in the USE Questionnaire with four (4) aspects of assessment, namely nervousness, ease of use, easy to learn and satisfaction. The list of questions can be seen in table 2 below.. 
Table 2. List of Questions on use questionnaire

\begin{tabular}{|c|c|c|c|c|c|c|}
\hline \multirow{2}{*}{\multicolumn{2}{|c|}{ Evaluation Criteria }} & \multicolumn{5}{|c|}{ Evaluation } \\
\hline & & \multirow[t]{2}{*}{ SS(1) } & \multirow[t]{2}{*}{$S(2)$} & \multirow[t]{2}{*}{$N(3)$} & \multirow[t]{2}{*}{ TS(4) } & \multirow[t]{2}{*}{ STS(5) } \\
\hline \multicolumn{2}{|c|}{ USEFULNESS } & & & & & \\
\hline 1 & It helps me be more effective. & & & & & \\
\hline 2 & It helps me be more productive. & & & & & \\
\hline 3 & It is useful. & & & & & \\
\hline 4 & $\begin{array}{l}\text { It gives me more control over the activities in } \\
\text { my life. }\end{array}$ & & & & & \\
\hline 5 & $\begin{array}{l}\text { It makes the things I want to accomplish easier } \\
\text { to get done. }\end{array}$ & & & & & \\
\hline 6 & It saves me time when I use it. & & & & & \\
\hline 7 & It meets my needs. & & & & & \\
\hline 8 & It does everything I would expect it to do. & & & & & \\
\hline \multicolumn{7}{|c|}{ EASE OF USE } \\
\hline 9 & It is easy to use. & & & & & \\
\hline 10 & It is simple to use. & & & & & \\
\hline 11 & It is user friendly. & & & & & \\
\hline 12 & $\begin{array}{l}\text { It requires the fewest steps possible to } \\
\text { accomplish what I want to do with it. }\end{array}$ & & & & & \\
\hline 13 & It is flexible. & & & & & \\
\hline 14 & Using it is effortless. & & & & & \\
\hline 15 & I can use it without written instructions. & & & & & \\
\hline 16 & I don't notice any inconsistencies as I use it. & & & & & \\
\hline 17 & Both occasional and regular users would like it. & & & & & \\
\hline 18 & I can recover from mistakes quickly and easily. & & & & & \\
\hline 19 & I can use it successfully every time. & & & & & \\
\hline \multicolumn{7}{|c|}{ EASE OF LEARNING } \\
\hline 20 & I learned to use it quickly. & & & & & \\
\hline 21 & I easily remember how to use it. & & & & & \\
\hline 22 & It is easy to learn to use it. & & & & & \\
\hline 23 & I quickly became skillful with it & & & & & \\
\hline \multicolumn{7}{|c|}{ SATISFACTION } \\
\hline 24 & I am satisfied with it. & & & & & \\
\hline 25 & I would recommend it to a friend. & & & & & \\
\hline 26 & It is fun to use. & & & & & \\
\hline 27 & It works the way I want it to work. & & & & & \\
\hline 28 & It is wonderful. & & & & & \\
\hline 29 & I feel I need to have it. & & & & & \\
\hline 30 & It is pleasant to use. & & & & & \\
\hline
\end{tabular}




\section{Results and Discussion}

1) Implementasi Design

Implementation is the stage of application creation after the process of stages for analysis and design of the interface is carried out. The implementation of the UCD approach results in an interface consisting of Login Page, dashboard, Admin/User, Data Master, Category and Marketplace.

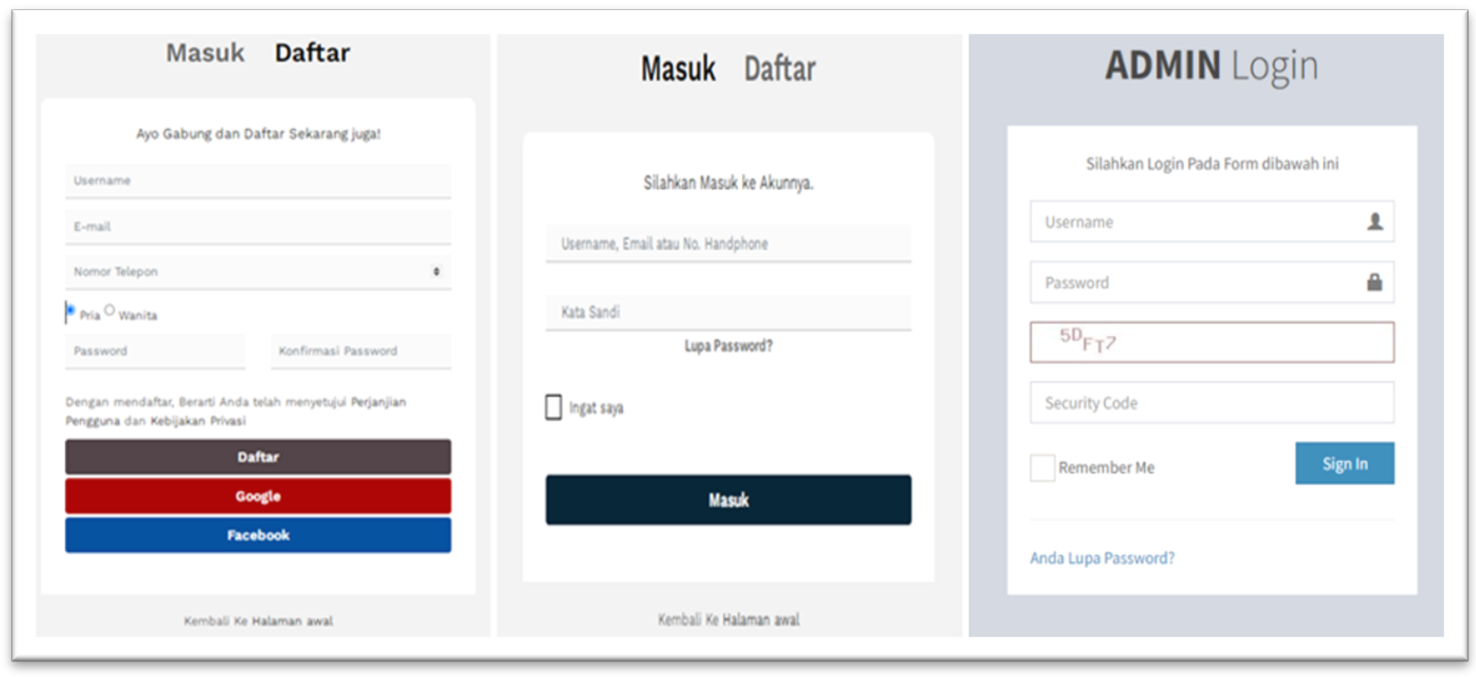

Figure 5. User Login/Register and Login Administrator pages

On the login page there are 3 permissions, namely a page that is specifically for administrators, an operator page that serves as an admin and a login / list page for msme / customer as seen in figure 5 .

On the operator's home page can be seen the status of the current condition, data and various information from UMKM in the scope of work of the Cooperative and UKM Office of South Aceh Regency as seen in figure 6.

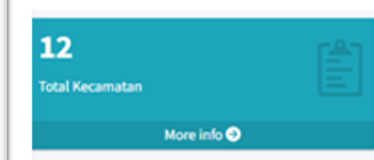

Sehtor UMKM

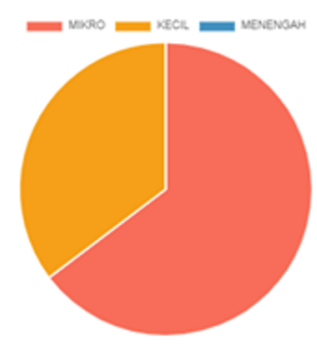

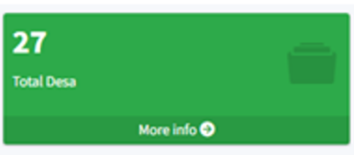

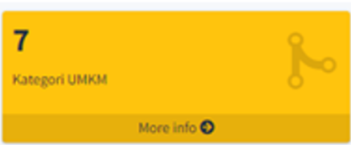

162

34

Total umika

More info $\ominus$

Rp. 289.745 .000

Rp. 146.981.500

omeret

Figure 6. Master Data Page

Fardiansyah et.al (Implementation of User Centered Design Method on e-Catalog Information System of UMKM in South Aceh Agency) 
On the administrator's home page contains user information that has been incorporated in the marketplace with product data of each UMKM that has been built by the Cooperative and UKM Office of South Aceh Regency as seen in figure 7.

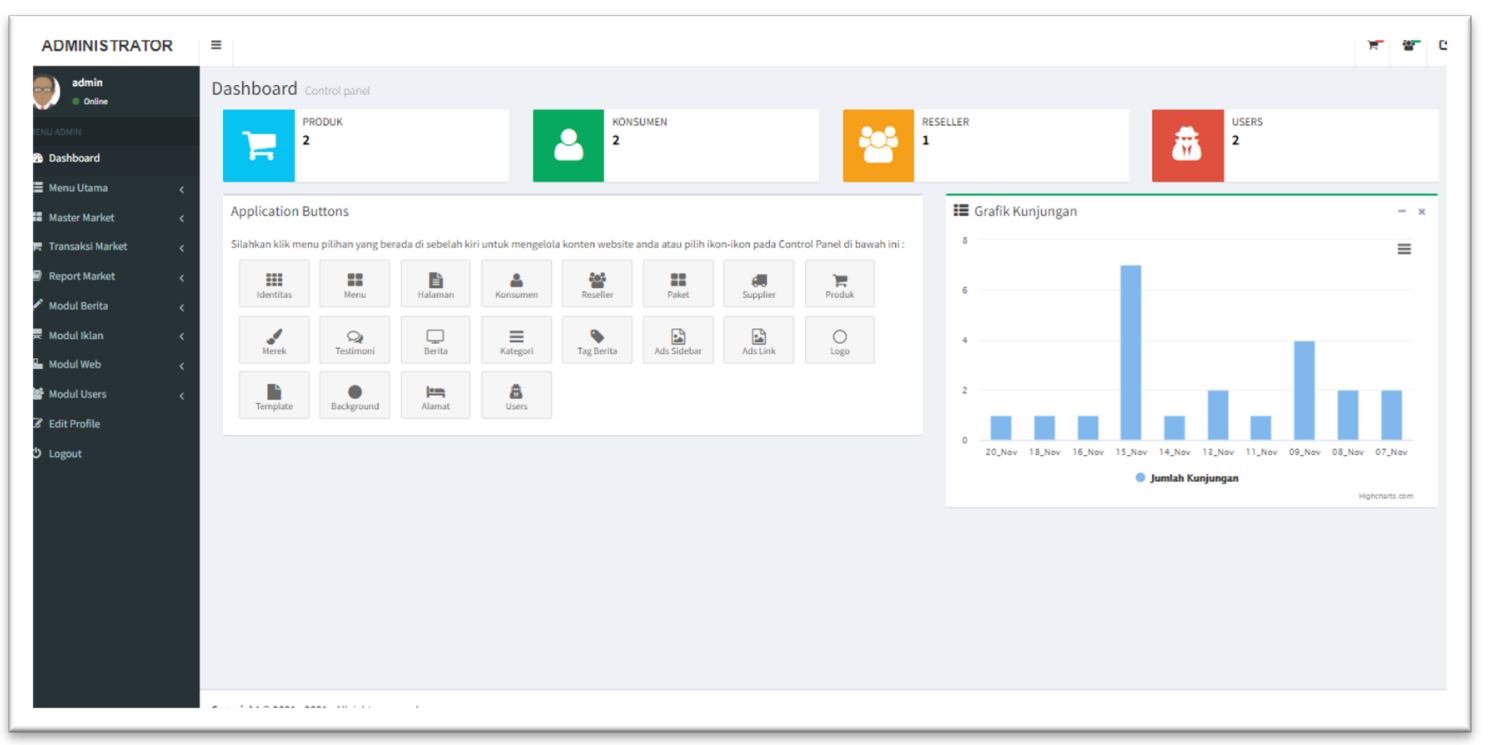

Figure 7. Administrator Pane Dashboard Page

On the business page can be seen the types of businesses that have been registered with the Cooperative Office and UMKM of South Aceh Regency. This page makes it possible for operators to carry out the process of adding data and updating data from each UKM based on the latest reporting results on the field.

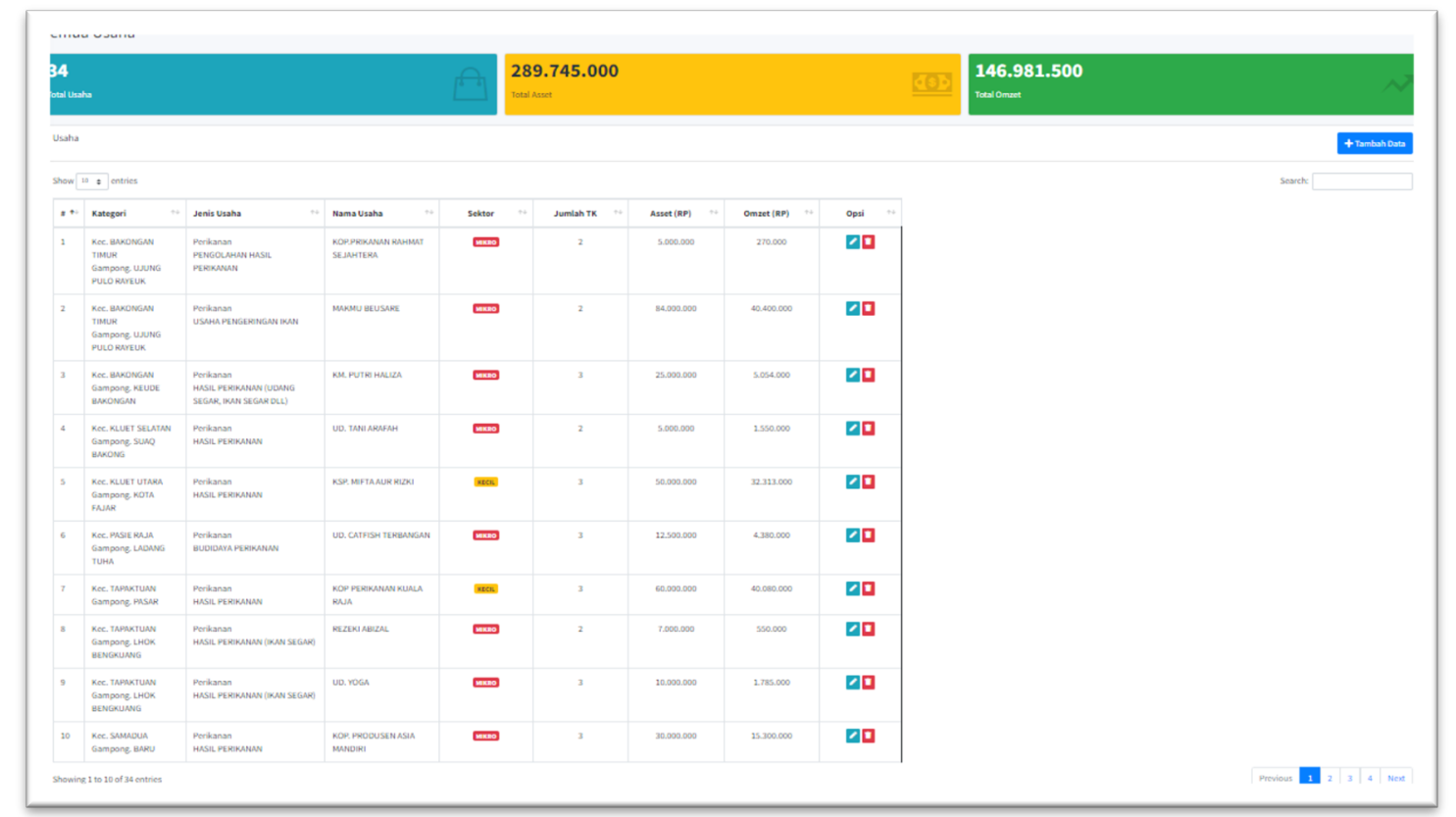

Figure 8. Business Dashboard Page 


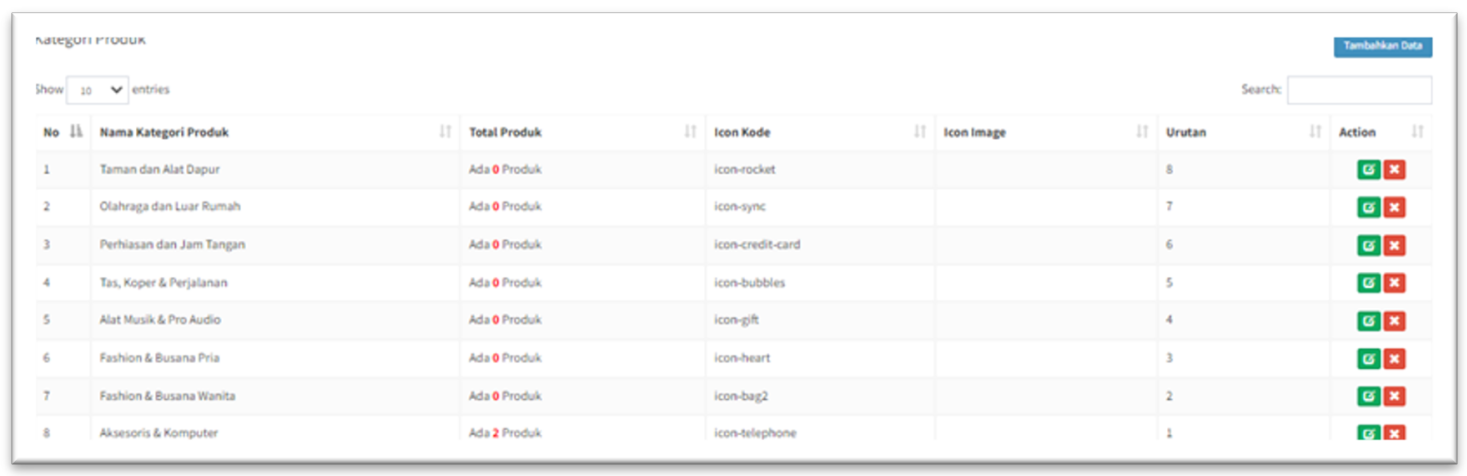

Figure 9. Product Category Page

On the product category page as seen in figure 3.11, filled by each UMKM to market its products on a marketplace managed by the Cooperative Service and UMKM. The product validation process is carried out previously by the agency before being marketed by UMKM.

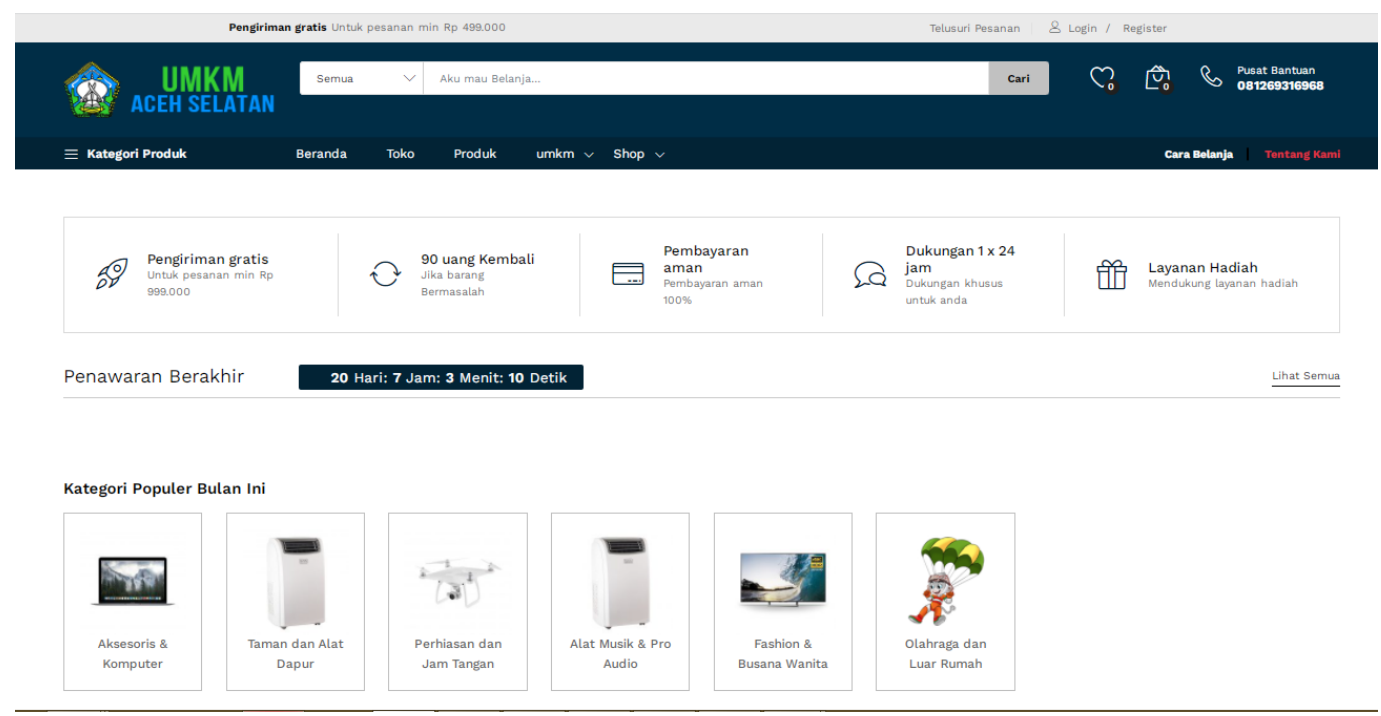

Figure 10. Marketplace Page

Figure 10 shows the market place page where customers can make buying and selling transactions with UMKM that utilize marketing provided by the Cooperative Office and UMKM of South Aceh Regency.

2) Evaluation of System Utilization

The data collection was carried out by spreading questionnaires in each group of UMKM categories. This group of categories is taken from UMKM users who have been registered into the system to get more valid data and information. Each respondent was given time in filling out a questionnaire that had been prepared in accordance with the respondent's experience in the use of the previous system. Table 3 shows the grouping and number of respondents used as sampling in the study. 
Table 3.UMKM Group Category and Number of Respondents

\begin{tabular}{clc}
\hline No & \multicolumn{1}{c}{ Group of Respondents } & $\begin{array}{c}\text { Number of } \\
\text { Respondents }\end{array}$ \\
\hline 1 & User (Customer) & 6 \\
\hline 2 & UKM Usaha Perdagangan & 6 \\
\hline 3 & UKM Usaha Peternakan & 6 \\
\hline 4 & UKM Usaha Perikanan & 6 \\
\hline 5 & UKM Usaha Perindustrian & 6 \\
\hline
\end{tabular}

Then data collection is processed by using the likert scale to find out or measure the opinions, perceptions, or attitudes of phenomena in the use of systems that have been built.

\section{Conclusion}

The quality classification of test results is grouped into 3 categories namely Good $(75 \%<\mathrm{x}$ $>=100 \%$ ), Enough $(55 \%<x>=75 \%)$, and Less $(x<=55 \%)$. Based on the test results for each criteria obtained results that are visualized into the form of graphs as follows:

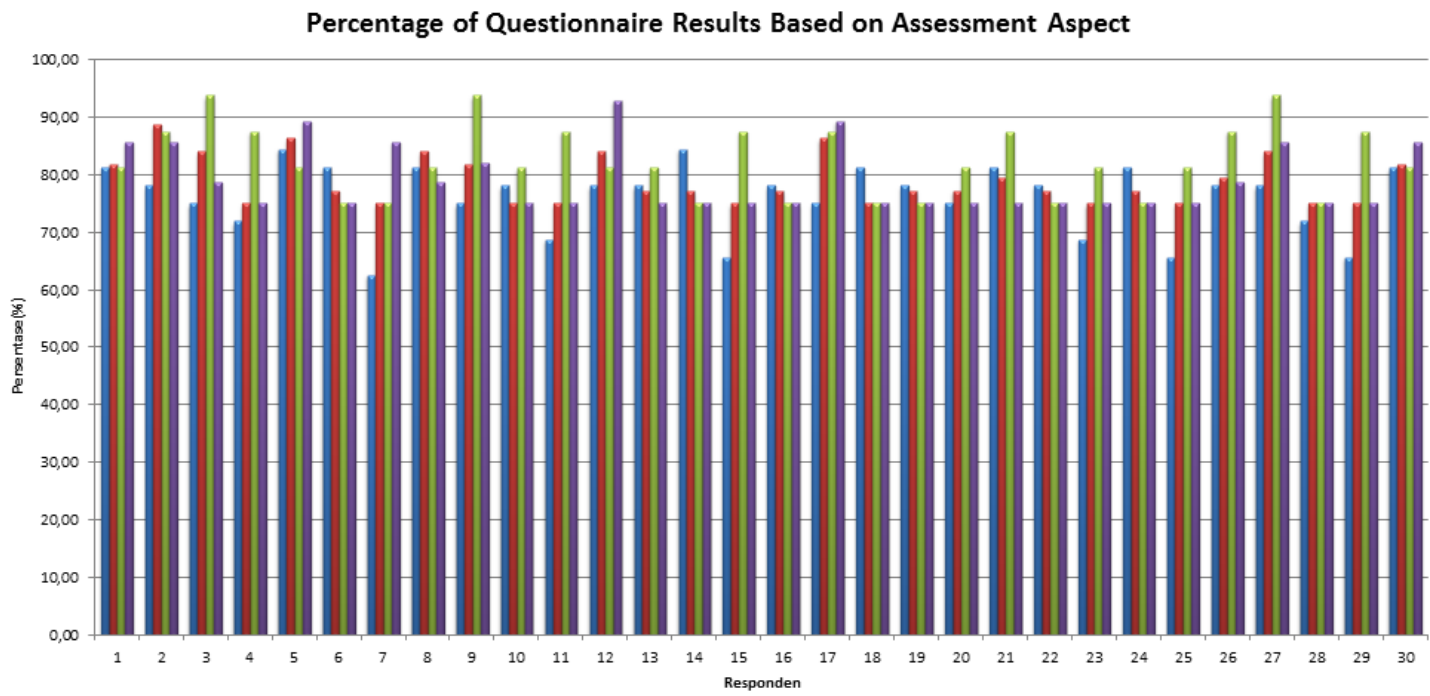

Figure 11. Percentage of Questionnaire Results Based on Assessment Aspects

Based on the results of the percentage of questionnaires that have been filled out by 30 respondents it is known that for the average respondent gives a good assessment of the system made. This case can be seen from the graph below: 


\section{System evaluation results}

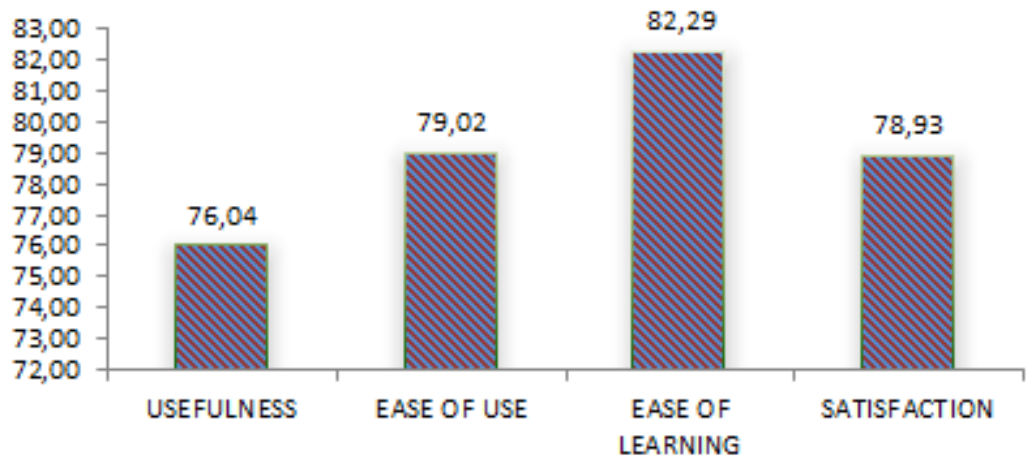

Assessment Aspects Based on USE Questionnaire

Figure 12. Average Percentage of Questionnaire Results Based on Assessment Aspects

\section{References}

[1] Badan Pusat Statistik, "Statistic E-Commerce 2019", ISSN / ISBN : 978-602-438-290-2, 2019.

[2] K.E.Kendall \& J.E. Kendall, "Analisis dan Perancangan Sistem", ISBN-978-979-683-800-4, Indeks, 2010.

[3] K.C.Laudon \& J. P. Laudon, "Management Information Systems : Managing the Digital Firm", ISBN13: 978-1-29209400-7, Pearson Education, 2014.

[4] Yakub,’Pengantar Sistem Informasi”, Graha Ilmu, Yogyakarta, 2012.

[5] Peraturan Lembaga Kebijakan Pengadaan Barang/Jasa Pemerintah (LKPP) Nomor 11 Tahun 2018 Tentang Katalog Elektronik.

[6] Y. A. Rahman, E. D. Wahyuni, and D. S. Pradana, "Rancang Bangun Prototype Sistem Informasi Manajemen Program Studi Informatika Menggunakan Pendekatan User Centered Design", Repositor, vol. 2, no. 4, pp. 503-510, 2020.

[7] Meiyuzi Gao, Philip Kortum, Frederick Oswald,"Psychometric Evaluation of the USE (Usefulness, Satisfaction, and Ease of use) Questionnaire for Reliability and Validity", SAGE Journals, Volume 62 Issue:1, page(s):1414-1418, 2018.

[8] Kriksciuniene D., Sakalauskas V., Lewandowski R. (2019) Evaluating the Interdependent Effect for Likert Scale Items. In: Abramowicz W., Corchuelo R. (eds) Business Information Systems Workshops. BIS 2019. Lecture Notes in Business Information Processing, vol 373. Springer, Cham. https://doi.org/10.1007/978-3-030-36691-9_3 